\section{Prólogo:}

\section{Arq uitectura simp lemente} José Domingo Peñafiel

Si bajamos a las zonas más profundas de la memoria y del recuerdo en busca de las claves que caracterizan las imágenes de una ciudad, de un barrio, de una región, podemos esforzarnos para descubrir cuáles son esos elementos esenciales que quedan fijos y hacen reconocible el lugar.

La ciudad o una parte de ella es reconocible desde el inconsciente. Hay lugares más claramente reconocibles que otros. Ciudades más características. Tal como unos pocos acordes contienen la información de una sinfonía completa que está almacenada en la mente y un leve aroma nos recrea un paisaje y un momento, hay unos pocos elementos arquitectónicos que nos vienen a la memoria y nos sitúan en un lugar con fuerza y realismo. Mediante un esfuerzo analítico se intentará develar cuáles pueden ser éstos elementos y por qué producen este resurgir de vivencias e imágenes completas del pasado.

Tal como ocurre en pintura y en otras manifestaciones artísticas, hay autores que han desarrollado un lenguaje muy personal y característico. Con sólo ver una pequeña superficie de una tela sabemos que estamos frente a una obra de Van Gogh o a una de Turner. Del

\title{
Lo cotidiano de
}

\section{la arq uitectura}
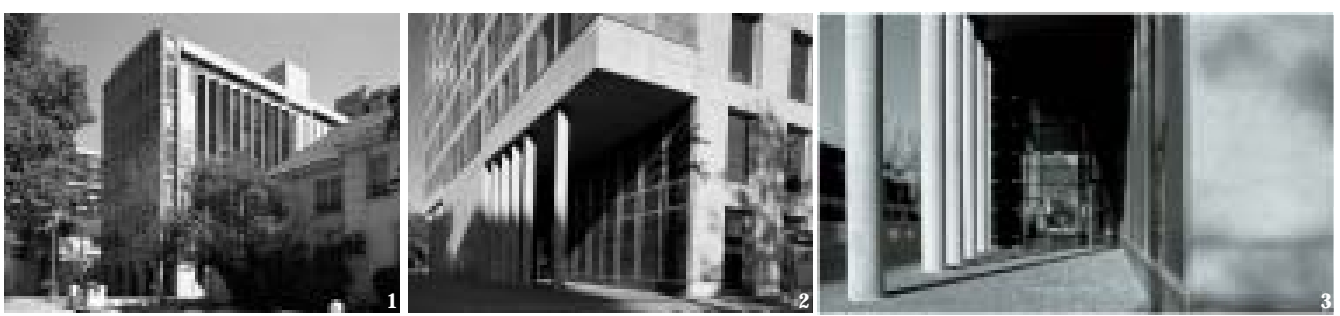

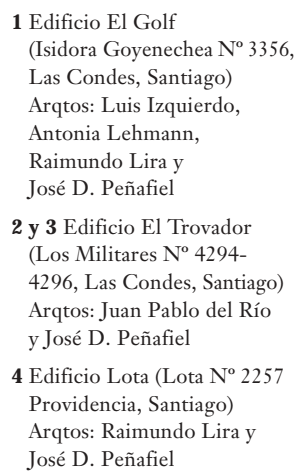

5 y 6 Edificio San Damián (San Damián No 450 , Las Condes, Santiago) Arqto: José D. Peñafiel 7 Edificio Telefonistas Télex (Fanor Velasco $\mathrm{N}^{\circ} 50$, Santiago)

Arqtos: Raimundo Lira y José D. Peñafiel

8 y 9 Casas Calle La Grulla, Los Nogales de la Dehesa. Arqto: José D. Peñafiel

\section{Prologue:}

\section{Simply architecture}

José Domingo Peñafiel

If we investigate the deepest corners of memory in search of the keys to the images of a city, a neighborhood, a region, we can make an effort to discover the essential elements that remain fixed and make a place recognizable.

The city or a part of it is recognizable even at an unconscious level. Some places are more clearly recognizable than others. Some cities are more typical. Just as a few chords can hold the information for a complete symphony that is stored in the mind, so a slight aroma can recreate a landscape and a moment, or a very small number of architectural elements come to mind and place us firmly in a specific place. We are going to try to identify these elements through analysis, looking at try to reveal what these elements might be and why they can bring past experiences and whole images so vividly back to life.

As occurs with painting and the other arts, some authors have developed a very personal and typical language. By looking at just a small square of canvas we know if we are looking at a work by Van Gogh or Turner. Similarly, by taking a stance in the midst of a work of architecture we can figure out with complete certainty that this is part 
mismo modo, con situarnos en medio de una obra de arquitectura sabremos con toda certeza que se trata de un proyecto de Niemeyer o uno de Le Corbusier. Son ejemplos extremos, en el sentido de que se trata de artistas cuyo lenguaje es personalísimo y único. Su vocabulario artístico es muy desarrollado y depurado y constituye algo así como una marca registrada. En el caso de Niemeyer, en que además construyó una zona urbana completa y coherente, como es el caso del centro de Brasilia, el ejemplo es aún más notable y único. Aquí no podemos hablar de arquitectura simplemente, sino debiera ser de arquitectura sorprendentemente. Otro caso similar podría ser la Acrópolis de Atenas que, visto con la perspectiva de los siglos, constituye una unidad majestuosa y de una belleza inigualable en la historia de la arquitectura.

Sin embargo, los ejemplos nombrados más arriba están mencionados para situar el tema donde nos interesa, ajustado al mundo actual y a la ciudad de Santiago. Se trata de la creación de la huella urbana a través de la arquitectura.

La formación de la masa urbana construida en Santiago se ha ido configurando a través de su historia mediante idas y venidas, avanzando por el tiempo a través de un camino dificultoso y errático. Varios factores determinaron que asî fuera. Santiago, ciudad lejana, pobre y esforzada. La suma de adobes, tejas y terremotos ha levantado y derrumbado construcciones durante cuatro siglos. Esto ha impedido marcar una historia urbana estable en el tiempo. Quedan unas pocas construcciones coloniales, pero no alcanzan a constituir una trama continua. Son casos aislados y tragados por el progreso. La ciudad se modernizó y los edificios se alivianaron y se levantaron del suelo. Construcciones de madera y adobe, más esbeltas y elegantes, al estilo europeo. Pero la vejez e inapropiada mantención también arrasó con este Santiago de principios del siglo XX. Se han hecho esfuerzos por rescatar estas construcciones, pero son pocas las que lograron mantener su dignidad constituyendo barrios viejos y en cuyo interior la vida moderna

\section{The every day quality of architecture}
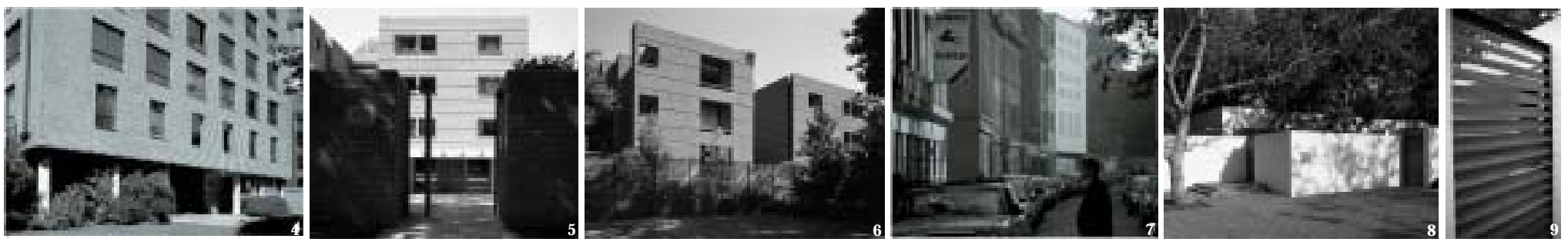

of a project by Niemeyer or Le Corbusier. These are extreme examples, in the sense that these are all artists whose language is extremely personal and unique. Their artistic vocabulary is very developed and refined, and constitutes something like a registered trademark. In the case of Niemeyer, who furthermore built a complete and consistent urban area, as is the case with the center of Brasilia, the example is even more noteworthy and unique. Here we cannot speak simply of architecture, but rather surprisingly of architecture.

The Acropolis in Athens offers another possibly similar case. Viewed from the perspective of centuries, it offers its majestic unity and a beauty unequalled in the history of architecture. The examples listed above, however, are mentioned to help frame the subject of our interest, adjusted to today's world and the city of Santiago. This is really about how one creates an urban impression through architecture.

The development of the urban mass built in Santiago has followed a difficult, zigzagging and often erratic path throughout history. Several factors contributed to this. Santiago, a distant city, poor and hard working. The combination of adobe, roof tiles and earthquakes has raised and crumbled buildings for four centuries, making it difficult to identify signs of a clear urban history that are stable over time. A handful of colonial buildings remain, but not enough to identity a continuous thread. They are exceptions, quickly swallowed up by progress. The city grew modern and buildings grew lighter and rose higher above the ground. Wood and adobe buildings took over, becoming slimmer and more elegant in the European style. But at the beginning of the $20^{\text {th }}$ century old age and unsuitable maintenance also swept away this Santiago. Some effort has been made to rescue these buildings, but few have successfully retained their dignity, becoming instead old neighborhoods in which modern life is uncomfortable and troublesome. In midcentury, the quality of buildings stabilized around modern parameters and a city of anti-seismic 
es incómoda y molesta. A mediados del siglo la calidad de la construcción ya estabilizó su calidad de acuerdo a los parámetros modernos y ya se vislumbraba una ciudad de casas y edificios asísmicos y de una materialidad más perdurable e incorruptible. El hecho de ser una ciudad joven y en pleno desarrollo ha tenido como consecuencia que la mayoría de estos barrios modernos han cambiado de destino y han sido violentamente transformados, destruyendo por la fuerza lo que se planificó como permanente, rompiendo la unidad con la que fueron planificados y sobreponiendo una nueva trama a una escala mayor, que ha producido una ruptura formal y de uso que tardará décadas en decantar y cuya infraestructura tampoco soporta estos implantes que le han sido impuestos.

Pero lo que nos interesa es lo que caracteriza a nuestra ciudad. En una época determinada, en uno de sus barrios o a través de una tipología específica que la conforma. No entraremos a revisar puntos singulares, ni revisaremos ejemplos descollantes en ningún aspecto.

En la ciudad de Nueva York, en el centro de Manhattan, el tejido urbano está compuesto por una suma de construcciones que conforman una unidad reconocible. Todos los edificios que

houses and buildings began to take shape, composed of more lasting and resistant materials. The fact that this is a young city at the height of development has brought sudden, violent changes in the zoning of these new neighborhoods, destroying by force all that was planned to become permanent, shattering the unity with which these areas were planned and forcing a new, larger-scale layer onto the city, producing a breakdown in terms of both the visual appeal and physical uses that will take decades to absorb and whose infrastructure has proven unable to bear the grafts imposed upon it. But what interests us is what gives our city its character. In a specific period, in one of its neighborhoods or through the specific typology that constitutes it. We will not approach this by reviewing unusual highlights or examples that are outstanding for one reason or another.

In the city of New York, in the center of Manhattan, the urban tissue is composed of a series of buildings that form a recognizable unit. All the buildings composing a block, a street, and a neighborhood have a clear, coherent urban face. Together they form a harmonic set of buildings. They are all of similar quality, made of recognizable materials, with similar configurations. componen una cuadra, una calle, un barrio, tienen una cara urbana clara y coherente. Son una serie de edificios compuestos en armonía. Todos tienen una calidad pareja, una materialidad reconocible, una configuración pareja. Nuestra memoria difícilmente podrá destacar particularidades, pero el resultado es unitario. Si tomamos cada construcción en forma aislada, descubriremos una manufactura de calidad, una arquitectura cuidada y noble, un especial cuidado en los detalles, dando un resultado notable. Si tomamos a la ciudad de Washington como ejemplo, el barrio de Georgetown en especial, nuevamente encontraremos esa unidad que nos llama la atención, caracterizada por las edificaciones de ladrillo, de una altura pareja con una morfología característica, configurando una imagen particular y única.

En Santiago la situación es diferente. Parece ser que esta unidad, esta armonía y homogeneidad están difícilmente presentes. No está la altura característica del barrio. No están los materiales reconocibles, no está el lenguaje arquitectónico preciso. Falta en nuestra ciudad esa reducción a lo esencial. A la arquitectura le falta el carácter dado por un lenguaje acotado. Le sobra protagonismo y "creatividad".

Estamos hablando de arquitectura. Siempre de

With difficulty, our memory distinguishes some unique features, but the overall result is one of unity. If we take each building individually, we will discover its quality, expressed through a noble and painstaking architectural design with specia attention to details, which altogether yield these noteworthy results. If we take the city of Washington, as our example, especially Georgetown, once again we find this unity that draws attention to itself, characterized by brick buildings, of similar height and characteristic shape, thus creating a particular, unique image. Santiago, however, is different. It seems that this unity, this harmony and homogeneity aren't really there. We don't find a specific height characterizing a neighborhood. Not are all materials recognizable, nor is the architectural language precise. Our city lacks this reduction to its essence. It architecture lacks the character bestowed by a clearly defined language. There's too much protagonism and "creativity".

We are speaking here of architecture. Always of architecture. This isn't about simplifying architectural language but rather controlling it. Our city lacks coherence, it lacks that character provided by neighborhoods composed of works of similar quality, built in the same spirit, during arquitectura. No se trata de simplificar el lenguaje arquitectónico, sino de acotarlo. A nuestra ciudad le falta coherencia, le falta ese carácter dado por los barrios constituidos por obras de calidad pareja, construidas bajo el mismo espíritu, en una misma época, impulsadas por objetivos comunes. Obras buenas, serias, finas, cuidadas, sin aspavientos y concebidas como partes de un todo, como una orquesta, donde todos los instrumentos están actuando bajo la batuta de un director y en función de una sinfonía y de un todo unitario, y no donde cada uno trata de sobresalir sobre el otro, creando un caos de ruidos donde la melodía queda sepultada en una mezcolanza ensordecedora. Las imágenes del Santiago colonial muestran una ciudad homogénea: siempre construcciones de adobe, bajas, modestas, pero reconocibles. El paisaje característico del valle central, con la cordillera al fondo, nítida, y el aire limpio. La vegetación que complementa la ciudad hasta hoy, los álamos, las avenidas frondosas en un paisaje árido, eso no ha cambiado mucho. Luego las imágenes del Santiago de principios del siglo XX son también reconocibles. Aparece una arquitectura afrancesada, a la moda europea, pero conservando esa modestia de la ciudad colonial. Sigue siendo una ciudad diferente a la anterior,

a single period, driven by common objectives. Works that are good, serious, fine and carefully produced, without fussiness, conceived as part of a whole, like an orchestra where all the instruments are played according to the movements of a single baton, and as a function of the symphony and a united whole, where no single element tries to stand out above the rest, creating a chaos of sounds that buries the melody in a deafening roar. Images of colonial Santiago show a homogeneous city: buildings are always made of adobe, are low, modest, but recognizable. We see the typical landscape of the central valley, with the Andes in the background, sharply defined, amidst clean air. The vegetation, which complements the city to this day, the poplars, the leafy avenues in an arid landscape: none of this has changed much. Images of Santiago in the early $20^{\text {th }}$ century are also recognizable. A Frenchified architecture appears, European style, but conserving the modesty of the colonial city. The city has changed from what it was before, but remains recognizable. These are not images of Paris, or Italian or Spanish cities. It's not Rio de Janeiro either, with its exuberant landscape and its Portuguese influence. Nor is it Buenos Aires with its grandiose proportions and the richness of its materials. Nor is it Lima 
pero reconocible. No son imágenes de París ni de una ciudad italiana ni española. Tampoco es Río de Janeiro con su paisaje exuberante y su influencia portuguesa, ni Buenos Aires con sus proporciones grandiosas y la riqueza de sus materiales, ni Lima con su pasado de esplendor colonial. Hacia mediados del siglo la extensión de la ciudad toma una velocidad creciente y crece perdiendo densidad.

¿Arquitectura simplemente versus qué? ¿Cuál sería la arquitectura no simplemente? Un recorrido por el Santiago de hoy nos dará una respuesta rotunda. La Alameda de las Delicias es hoy, en cuanto a su trazado, la misma de hace cien años. Entre La Moneda y la Estación Central un breve análisis entregará conclusiones sorprendentes. Quedan algunas que marcan el perfil de la calle. Las líneas arquitectónicas clásicas europeas son aún reconocibles. Se trata de antiguas casas de fachada continua a la calle y que sobreviven con dificultad a la ciudad de hoy. El cambio de destino las ha hecho soportar los avisos luminosos en fachadas y techos. Han sido pintadas de colores que les han arrancado parte de su dignidad. Otras, con sus fachadas cubiertas por materiales sin nobleza para vestirse a la moda y atraer al comprador. El comercio ha invadido el barrio.

caught in the splendor of its colonial past. Toward the middle of the century, urban sprawl picks up speed and the city grows, losing density.

Simply architecture versus what? What would be the un-simple equivalent? A journey through Santiago today provides a clear answer. The Alameda de las Delicias is today, in terms of its layout the same as it was a hundred years ago. Between the Moneda Palace and Central Station (Estación Central), a brief analysis leads to some surprising conclusions. The classic lines of European architecture remain recognizable even today. These are old houses with continuous facades lining the street and they survive with difficulty in today's city. The change in the area's zoning has brought flashing advertisements to facades and roofs, which have been painted in colors that destroy some of their dignity. Other buildings have had their facades covered with materials of poor quality to look more fashionable and attract buyers. Commerce has invaded the neighborhood. Electric goods and car repairs for sale have replaced the family life that once took place inside. This is the development of the city. But the area has lost its unity and identity. The old houses rub elbows with the buildings that, starting in the 1970s replaced others, with no
Artículos eléctricos y repuestos de automóviles a la venta han reemplazado la vida familiar de los interiores. Es el desarrollo de la ciudad. Pero se perdió la unidad y la identidad del lugar. Las viejas casas conviven con construcciones que a partir de los años '70 reemplazaron a otras, sin respetar nada del espíritu del lugar. Construcciones en metal, vidrio, plástico, formas caprichosas, gratuitas, vulgares, cubiertas por ese manto de polvo gris que baña a Santiago. Y así como el centro de Santiago está sufriendo esta transformación, algo parecido pero no igual ha sucedido con Providencia y con otros barrios de la ciudad que tenían su identidad grabada en sus calles. Por otros lados vemos ejemplos de lo que no debió ser en algún lugar de la ciudad. Construcciones que no se integran a su entorno, que buscan protagonismo en forma equivocada destruyendo el lugar. Es difícil saber si con el tiempo esta nueva ciudad llena de desaciertos urbanos conformará un todo unitario y los desaciertos se amarrarán produciendo un resultado positivo. No parece que será así.

Cuando un pintor se prepara para comenzar a pintar, hace previamente un trabajo de selección. Elige el medio con el cual se trabajará. Luego elige los materiales apropiados a emplear. Entonces, selecciona su gama de colores al igual

respect for the spirit of the place. Buildings of metal, glass, plastic, capricious, gratuitous, vulgar shapes, all covered with the mantels of gray dust typical of Santiago. And just as the center of Santiago has suffered this transformation, something similar has struck Providencia and other neighborhoods that once had their identity engraved in their streets. In other areas we see examples of what should not occur in any part of the city: buildings that are not integrated into their surroundings, that seek to stand out in a mistaken way that destroys the place. It is hard to know if, with time, this new city, full of urban blunders will eventually come together into a united whole, tying these errors together into a single positive result. This seems unlikely to occur. When a painter gets ready to paint, the first step is to complete a selection process. She or he chooses the medium in which to work and chooses the appropriate materials. Then comes a range of colors, just as the musician selects a range of sounds to use in composing music. Without this prior step of selecting the media and defining the artistic language to be used in the development of the work, the result will be unintelligible. It seems possible that the problem with Santiago's architecture today has something que un músico selecciona la gama de sonidos que empleará para componer su música. Si no existe este trabajo de selección de medios, de definir el idioma artístico del cual dispondrá para desarrollar su obra, el resultado será ininteligible. Parece ser posible que el problema de la arquitectura de Santiago en la actualidad tenga que ver con el lenguaje artístico y del alfabeto arquitectónico empleado para desarrollar las obras. Una mirada atenta a la ciudad hoy hace pensar en que no hay una selección de elementos para componer las obras de arquitectura. Tal vez se ha entendido mal la libertad que permite la tecnología hoy, y que la arquitectura en general, por supuesto sin incluir innumerables obras de mucha calidad, se está haciendo sin controlar elementos, materiales y formas en la composición de proyectos.

osé Domingo Peñafiel

Arquitecto, PUC de Chile, 1975. Desde 1977 trabajó asociado con el arquitecto Manuel Urrejola hasta su muerte en 1980. Luego forma oficina con el arquitecto Raimundo Lira hasta 1987. Desde esa fecha se asocian para diversos proyectos. Ha desarrollado proyectos de casas de muebles, escenda y oficina, industrias, in

to do with the artistic language and the architectural alphabet used to develop its works. Closer scrutiny of the city today leads one to think that there has been no selection of the elements to be used on composing its architectural works. Perhaps the freedom allowed by today's technology has been misunderstood, and architecture in general, excluding of course many works of great quality, is being carried out with no control of elements, materials and forms in the composition of projects. 